\title{
Nutritional content and antioxidant properties of edible indigenous wild fruits from miombo woodlands in Tanzania
}

\author{
E. Pensia MAPUNDA ${ }^{1,2^{*}}$ and Cosmas MLIGO $^{2}$ \\ ${ }^{I}$ Department of Conservation Biology, University of Dodoma, Tanzania. \\ ${ }^{2}$ Department of Botany, University of Dar es Salam, Tanzania. \\ "Corresponding author; E-mail: pensiamapundaa@yahoo.com
}

\begin{abstract}
Edible fruits of four indigenous plants (Uapaca kirkiana, Strychnos cocculoides, Syzygium guineense and Ximenia caffra) from miombo woodlands of Ruvuma Region in Tanzania were evaluated for nutritional composition and antioxidant properties. Fruits from the four plants were collected for extraction of the edible portion that was subsequently subjected to laboratory analysis using standard procedures. Soluble carbohydrates dominated among macronutrients evaluated (16.326 to $56.001 \%$ ) and potassium was the most abundant mineral nutrient among those studied with the concentration ranging from 429.4 to $671.73 \mathrm{mg} / 100 \mathrm{~g}$. The total phenolic contents, flavonoids and vitamin C in X. caffra were $1915.88 \mathrm{mg}$ GAE/100 g, $178.46 \mathrm{mg} \mathrm{RE}$ $/ 100 \mathrm{~g}$ and $359.90 \mathrm{mg} / 100 \mathrm{~g}$ respectively which are significantly higher than those in other species studied. Similarly, $X$. caffra showed significantly higher free radical scavenging activity with lower $\mathrm{EC}_{50}$ (effective concentration for free radical reduction by 50\%) achieved at $0.08 \mu \mathrm{g} / \mathrm{ml}$ than other fruit species studied. A strong positive correlation was observed between free radical scavenging activities with vitamin $\mathrm{C}(r=0.973)$, total phenolics $(r=0.866)$ and flavonoids $(r=0.858)$. These observations imply that indigenous fruits studied could be used as valuable sources of nutrients and vital natural antioxidant to human diets.
\end{abstract}

(C) 2019 International Formulae Group. All rights reserved

Keywords: Macronutrients, minerals, phenolics, flavanoids, vitamin C, Free radical scavenging.

\section{INTRODUCTION}

Miombo woodland is a common vegetation type found in the Eastern, Central and Southern African countries covering a total area of about 2.7 million $\mathrm{km}^{2}$ (Backéus et al., 2006). The woodland is dominated by three plant species of Brachystegia, Julbernardia and Isoberlinia genera (Backéus et al., 2006). The woodland provides local communities with important goods and services including indigenous fruits (Akinnifesi et al., 2006). Several indigenous fruits are good sources of carbohydrates, protein, fat, vitamins, and minerals that may be deficient in common diets (Leakey et al., 2005). Studies on some indigenous fruits like Adansonia digitata, Parinari curatellifolia, Vangueria infausta and Vitex doniana showed a substantial quantity of nutritive elements than the domesticated fruits that are commonly consumed by the local communities (Ruffo et al., 2002; Ndabikunze et al., 2006; Prasad et al., 2011). Fruits not only provide nutritive contents, but are also a 
natural source of antioxidant attributed to various phytonutrients contained such as phenolics and flavonoids (Boeing et al., 2012). Antioxidants are free radical scavengers and can significantly reduce oxidative damage in the human body (Atolani et al., 2012; Boeing et al., 2012).

The uses of edible indigenous fruits in tropical and subtropical Africa have been documented however, data on the nutritional composition and antioxidant potential is limited (Ndabikunze et al., 2006). In Tanzania there are few reports on the nutritional composition of some indigenous fruits (Ndabikunze et al., 2006; 2010) but data on phytonutrients and their antioxidant capacity are missing. Therefore in this study the chemical composition and antioxidant capacity in four indigenous fruit species namely Uapaca kirkiana, Strychnos cocculoides, Syzygium guineense and Ximenia caffra from Miombo woodlands of Ruvuma Region in Tanzania were evaluated for the purpose of creating awareness on nutritional and antioxidant value of the fruits.

\section{MATERIALS AND METHODS \\ Fruit sampling and preparation}

Ripe fruits of the four plant species were collected in five districts of Ruvuma Region in Tanzania during October 2015 to January 2016. Samples were packed in cooler boxes and transported to the University of Dar es Salaam laboratory for analysis. In the laboratory, fruits were washed thoroughly with distilled water to remove any attached impurities and dried using blotting paper. They were then stored as frozen fresh sample and oven dried sample until analysis.

\section{Proximate analysis}

Moisture content was determined by comparing the weight of fresh sample and oven dried sample at $110{ }^{\circ} \mathrm{C}$ for four hours according to the AOAC standard method (AOAC, 2000). Crude protein was determined using micro Kjeldahl method to obtain percentage nitrogen that was multiplied by factor 6.25 to estimate the content of crude protein (AOAC, 2000). Fat content was determined by continuous extraction with diethyl ether using Sohxlet apparatus (James, 1995). Fibre content was analyzed following procedures outlined in AOAC (2000). Soluble carbohydrate was determined calorimetrically using the procedures described by Allen (1989).

\section{Determination of minerals}

Mineral contents were determined using the method described by Allen (1989) where 0.1 gram of dried fruit sample was weighed into Kjeldal flask and $5 \mathrm{ml}$ conc. $\mathrm{HNO}_{3}$ was added followed by $1 \mathrm{ml}$ of perchloric acid and then digested at $120{ }^{\circ} \mathrm{C}$ until the mixture was colorless. The solution was then diluted with distilled water to $100 \mathrm{ml}$ solution that was used to determine the concentration of $\mathrm{Na}, \mathrm{K}, \mathrm{Ca}, \mathrm{Fe}$ and $\mathrm{Zn}$ through Atomic Absorption Spectrophotometer. The amount of phosphorus was determined from a portion of the filtrate obtained above using ascorbic acid method described by Olsen and Sommers (1982).

\section{Determination of vitamin $\mathrm{C}$ in the fruit extract}

Vitamin $\mathrm{C}$ was determined by using the procedure outlined by Klein and Perry (1982). Ten grams of fruit extract were treated with $20 \mathrm{ml}$ of metaphosphoric acid and filtered through Whatman No. 4 filter paper. The filtrates $(2 \mathrm{ml})$ were mixed with $18 \mathrm{ml}$ of indophenol dye and the absorbance was measured within $30 \mathrm{~min}$ at $515 \mathrm{~nm}$ against a blank. Content of ascorbic acid was calculated on the basis of the calibration curve of authentic L-ascorbic acid

\section{Determination of total phenolics in the fruit extracts}

Total phenolic content of the fruits sample was determined using the FolinCiocalteu reagent (Kähkönen et al., 1999). Appropriate diluted fruit extracts $(200 \mu \mathrm{l})$ were oxidized with $1 \mathrm{ml}$ of Folin -Ciocalteu reagent and mixed for 3 minutes and then 0.8 $\mathrm{ml}$ of $7.5 \%$ sodium carbonate were added. The mixture was agitated with a vortex mixer and allowed to stand for 30 minutes in the dark 
then centrifuged for 5 minutes. The absorbance of the fruit extracts was measured at $765 \mathrm{~nm}$ using spectrophotometer. The total phenol content was subsequently calculated from the calibration standard curve of gallic acid (GA) obtained from Sigma that was prepared by using a known concentration. The amount of phenolic content was expressed as gallic acid equivalent (GAE) per gram of fresh weight of fruit sample.

\section{Determination of total flavonoids in the fruit extracts}

Total flavonoid content in the fruit samples was determined according to the procedure described by Bonvehi et al., (2001). One milliliter of $0.5 \%$ hexamethyl tetramine, $20 \mathrm{ml}$ of acetone and $2 \mathrm{ml}$ of $0.1 \mathrm{M} \mathrm{HCl}$ were added to $5 \mathrm{~g}$ of finely ground thawed-frozen fruit extracts and boiled under reflux for 30 minutes. The resultant solution was filtered using Whatman paper No. 4 and the residues were further washed with $20 \mathrm{ml}$ of acetone then the filtrate was finally adjusted with acetone to $100 \mathrm{ml}$. Ten milliliters of the filtrate from each fruit extract was pipetted into a separating funnel along with $20 \mathrm{ml}$ of distilled $\mathrm{H}_{2} \mathrm{O}$ and then the aqueous phase was extracted with $25 \mathrm{ml}$ of ethyl acetate. The total amount of extract in the ethyl acetate layer collected from the separating funnel was subsequently adjusted to $100 \mathrm{ml}$ with ethyl acetate. To determine the total flavonoids, 10 $\mathrm{ml}$ of the ethyl acetate extract was pipetted into a test tube and mixed with $1 \mathrm{ml}$ of $2 \%$ $\mathrm{AlCl}_{3}$ dissolved in methanol containing 5\% acetic acid. The absorbance of the resulting solution was measured at $425 \mathrm{~nm}$ using a spectrophotometer. Total flavonoid content was calculated from the calibration standard curve of rutin (R) obtained from Sigma that was prepared by using a known concentration. The amount of flavanoids was expressed as rutin equivalent (RE) per gram of fresh weight of fruit sample.

\section{Determination of free radical scavenging activity of the fruit extract}

The free radical scavenging activity of the fruit extract was determined using stable radical 2, 2-diphenyl-1-picrylhydrazyl (DPPH) as described by Masuda et al., (1999). A series of extract concentrations with different ratios of extract to methanol $(1: 10$, $1: 10^{2}, 1: 10^{3}$ and $\left.1: 10^{4}\right)$ were prepared. Then $4.9 \mathrm{ml}$ of dilute extract was mixed with $100 \mu \mathrm{l}$ of $5 \mathrm{mM}$ DPPH in methanol and the mixture was placed in the dark for 30 minutes. The absorbance of fruit extract containing DPPH, the fruit extract diluted without DPPH and the DPPH solution without extract was read at $517 \mathrm{~nm}$ using spectrophotometer. All determinations were performed in triplicate and the percentage of DPPH of each plant extract determined at these four concentrations was calculated. DPPH radicalscavenging activity of each fruit extract was also plotted against their concentrations to determine the amount of extract necessary to decrease DPPH concentration by $50 \%\left(\mathrm{EC}_{50}\right)$.

\section{Statistical analysis}

Nutritional composition and antioxidant activities of the four fruit species were compared using Analysis of Variance (ANOVA) followed by a post hoc based on Tukey Kramer Multiple Comparison Tests at $\mathrm{P}<0.05$. Correlation between phenolics, flavonoids and vitamin $\mathrm{C}$ contents with free radical scavenging activity was determined using Pearson's correlation coefficient (r).

\section{RESULTS}

\section{Proximate analysis}

Data on proximate analysis have been presented in Table 1 where the fruits have remarkable high moisture content that varied significantly among species. Uapaca kirkiana had significantly lower moisture content than S. guineense, $(\mathrm{LSD}=6.430, \mathrm{q}=10.598$ and $\mathrm{P}$ $<0.001), X$. caffra $(\mathrm{LSD}=4.510, \mathrm{q}=7.434$ and $\mathrm{P}<0.001$ ) and $S$. cocculoides (LSD = 2.796, $\mathrm{q}=4.609$ and $\mathrm{P}<0.01$ ). Crude protein content ranged from $0.11 \%$ to $0.94 \%$ in $U$. kirkiana and $S$. cocculoides respectively. Based on one-way analysis of variance percentage protein were significantly different among the four studied species $(\mathrm{F}=294.69$, $\mathrm{DF}=87, \mathrm{P}<0.0001)$ and Turkey`s test showed that, each species had protein content 
that was significantly different from the other. While the result of crude fibre showed that $S$. guineense had a significantly higher amount of $31.34 \%$ compared to that of U. kirkiana ( $\mathrm{LSD}=23.098, \mathrm{q}=69.892$ and $\mathrm{P}<0.001$ ), $X$. caffra $(\mathrm{LSD}=17.742, \mathrm{q}=53.685$ and $\mathrm{P}<$ $0.001)$, and $S$. cocculoides $(\mathrm{LSD}=16.890, \mathrm{q}=$ 51.106 and $\mathrm{P}<0.001)$ that had $8.24,13.60$ and $14.45 \%$ respectively. Soluble carbohydrates in the studied fruits varied between $24.31 \%$ and $56.01 \%$ in X. caffra and $S$. cocculoides respectively. The differences among the four species were also significantly different $(\mathrm{F}=1650.5, \mathrm{DF}=87$, and $\mathrm{P}<$ 0.0001 ) and the post hoc test based on Turkey`s test showed the content recorded differed significantly among the four species. Among macronutrients studied the content of crude fat was generally low in all indigenous fruits having the value ranging from 0.0001 to $0.0032 \%$. However, the content recorded among the four studied fruit species were significantly different $(\mathrm{F}=75.927, \mathrm{DF} 87$, and $\mathrm{P}<0.0001$ ).

\section{Mineral composition}

The contents of mineral nutrients evaluated in the indigenous fruits shown in Table 2 indicates that potassium was the most abundant with amount ranging from 429 to $672 \mathrm{mg} / 100 \mathrm{~g}$ in X. caffra and U. kirkiana respectively. The amount of potassium content recorded in $X$. caffra was significantly higher than $U$. kirkiana $(\mathrm{LSD}=242.37, \mathrm{q}=$ 13.711, $\mathrm{P}<0.001)$ and $S$. cocculoides $(\mathrm{LSD}=$ 195.06, $\mathrm{q}=11.035, \mathrm{P}<0.001)$. The content of phosphorous varied significantly from 49.81 to $128.29 \mathrm{mg} / 100 \mathrm{~g}$ in $U$. kirkiana and $X$. caffra respectively $(\mathrm{F}=108.33, \mathrm{DF}=87, \mathrm{P}<$ 0.0001 ) and calcium from 23.18 to 58.96 $\mathrm{mg} / 100 \mathrm{~g}$ in $X$. caffra and $S$. cocculoides respectively $(\mathrm{F}=422.06, \mathrm{DF}=87, \mathrm{P}<$ $0.0001)$. While, iron content ranged from 1.76 to $20.39 \mathrm{mg} / 100 \mathrm{~g}$ being significantly higher in $X$. caffra than in $S$. guineense (LSD = 18.634, $\mathrm{q}=66.383, \mathrm{P}<0.001)$, S. cocculoides $(\mathrm{LSD}=14.739, \mathrm{q}=52.508, \mathrm{P}<0.001)$ and $U$. kirkiana $(\mathrm{LSD}=10.116, q=36.040, P<$ 0.001 ). The study recorded low amount of sodium and zinc in all studied fruit species.
However, the differences among species are significant. Sodium content ranged from 0.69 $\mathrm{mg} / 100 \mathrm{~g}$ in $S$. guineense to $2.11 \mathrm{mg} / 100 \mathrm{~g}$ in U. kirkiana $(\mathrm{F}=10.017, \mathrm{DF}=87$ and $\mathrm{P}<$ 0.0001 ) and zinc from $0.01 \mathrm{mg} / 100 \mathrm{~g}$ in $U$. Kirkiana and S. cocculoides to $0.04 \mathrm{mg} / 100 \mathrm{~g}$ in $S$. guineense $(\mathrm{F}=5.539, \mathrm{DF}=87$ and $\mathrm{P}=$ 0.0016).

\section{Total phenolic content (TPC)}

Results for TPC investigated are shown in Table 3. Among fruit extracts, total phenolic content ranged from 137.37 to $1915.88 \mathrm{mg} \mathrm{GAE} / 100 \mathrm{~g}$ in S. guineense and X. caffra respectively and the differences among species were extremely significant $(\mathrm{F}=$ $1480.7, \mathrm{DF}=87, \mathrm{P}<0.0001)$ based on oneway analysis of variance. Also, Turkey`s test showed that the phenolic content recorded in $X$. caffra is significantly higher than in $S$. guineense $(\mathrm{LSD}=1778.5, \mathrm{q}=83.078, \mathrm{P}<$ $0.001), U$. kirkiana $(\mathrm{LSD}=1660.5, \mathrm{q}=$ $77.565 \mathrm{P}<0.001)$ and $S$. cocculoides (LSD = 1423.6, $\mathrm{q}=66.497, \mathrm{P}<0.001$ ).

\section{Total flavonoid contents (TFC)}

Data on flavonoid content are shown in Table 3. This study observed a significant variation of flavonoid content among species ranging from 45.24 to $178.46 \mathrm{mg} R E / 100 \mathrm{~g}$ (F $=382.42, \mathrm{DF}=87, \mathrm{P}<0.0001)$. Significant higher flavonoid content was recorded in $X$. caffra than it was in $S$. guineense (LSD = 133.25, $\mathrm{q}=42.581, \mathrm{P}<0.001)$, U. kirkiana $(\mathrm{LSD}=122.52, q=39.152, P<0.001)$ and $S$. cocculoides $(\mathrm{LSD}=104.3, \mathrm{q}=33.354, \mathrm{P}<$ 0.001).

\section{Vitamin $C$ content}

The amount of vitamin $\mathrm{C}$ ranged from 53.91 to $358.82 \mathrm{mg} / 100 \mathrm{~g}$ in the studied species as shown in Table $3(\mathrm{~F}=2276.5, \mathrm{DF}=$ 87, $\mathrm{P}<0.0001)$. Ximenia caffra had significantly higher vitamin $\mathrm{C}$ content than $U$. kirkiana, $(\mathrm{LSD}=304.91, \mathrm{q}=105.82, \mathrm{P}<$ 0.001) S. cocculoides $(\mathrm{LSD}=265.79, \mathrm{q}=$ 92.245, $\mathrm{P}<0.001)$ and $S$. guineense $(\mathrm{LSD}=$ 237.14, $\mathrm{q}=82.304, \mathrm{P}<0.001)$ based on Turkey`s test. 


\section{DPPH radical scavenging activity}

DPPH is stable radical used to examine the free radical scavenging ability of food materials and bioactive compounds. From this study, free radical scavenging activities increased with the increase in concentration of the fruit extracts as depicted in Figure 1. In each concentration $X$. caffra had significant higher scavenging activity than other species studied ( $\mathrm{P}<0.05)$. At a concentration of 10 $\mu \mathrm{g} / \mathrm{ml} X$. caffra had significantly higher free radical scavenging activity of $96.70 \%$ than in U. kirkiana $(\mathrm{LSD}=14.312 \mathrm{q}=8.176, \mathrm{P}<$
0.001), $S$. cocculoides $(\mathrm{LSD}=11.297, \mathrm{q}=$ $6.454, \mathrm{P}<0.001)$ and $S$. guineense $(\mathrm{LSD}=$ 7.950, $\mathrm{q}=4.541, \mathrm{P}<0.05)$ that had 82.38, 85.40, and $88.74 \%$ respectively. Among extracts of the fruits studied, the $\mathrm{EC}_{50}$ values were in the order; Ximenia caffra $<$ Syzygium guineense < Uapaca kirkiana < Strychnos cocculoides $(0.08,0.18,0.78$ and $0.80 \mu \mathrm{g} / \mathrm{ml}$ respectively) as shown in Figure 2. Also, were positively correlated with the amount of vitamin $\mathrm{C}(\mathrm{r}=0.973)$ followed by phenolics $(\mathrm{r}$ $=0.866)$ and flavonoids $(\mathrm{r}=0.858)$ as shown in Figure 3.

Table 1: Proximate composition of the indigenous fruit species.

\begin{tabular}{lllllll}
\hline & & \multicolumn{5}{l}{ Composition (\%) } \\
\cline { 3 - 6 } Species names & Family names & Moisture & Fibre & Protein & Fat & Carbohydrate \\
\hline X. caffra & Euphorbiaceae & $84.00 \pm 0.09^{\mathrm{ab}}$ & $13.60 \pm 0.26^{\mathrm{b}}$ & $0.72 \pm 0.03^{\mathrm{b}}$ & $0.0001 \pm 00^{\mathrm{d}}$ & $24.31 \pm 0.23^{\mathrm{c}}$ \\
S. guineense & Myrtaceae & $85.92 \pm 0.63^{\mathrm{a}}$ & $31.34 \pm 0.53^{\mathrm{a}}$ & $0.23 \pm 0.01^{\mathrm{c}}$ & $0.0002 \pm 00^{\mathrm{c}}$ & $16.33 \pm 0.35^{\mathrm{d}}$ \\
S. cocculoides & Loganiaceae & $82.28 \pm 0.66^{\mathrm{b}}$ & $14.45 \pm 0.22^{\mathrm{b}}$ & $0.94 \pm 0.03^{\mathrm{a}}$ & $0.0013 \pm 00^{\mathrm{b}}$ & $56.01 \pm 0.57^{\mathrm{a}}$ \\
U. kirkiana & Olacaceae & $79.49 \pm 0.95^{\mathrm{c}}$ & $8.24 \pm 0.19^{\mathrm{c}}$ & $0.11 \pm 0.01^{\mathrm{d}}$ & $0.0032 \pm 00^{\mathrm{a}}$ & $35.64 \pm 0.47^{\mathrm{b}}$ \\
\hline \multirow{2}{*}{ ANOVA } & & $\mathrm{F}=20.22$ & $\mathrm{~F}=916.75$ & $\mathrm{~F}=294.69$ & $\mathrm{~F}=75.927$ & $\mathrm{~F}=1650.5$ \\
& & $\mathrm{DF}=87$ & $\mathrm{DF}=87$ & $\mathrm{DF}=87$ & $\mathrm{DF}=87$ & $\mathrm{DF}=87$ \\
\hline & & $\mathrm{P}<0.0001$ & $\mathrm{P}<0.0001$ & $\mathrm{P}<0.0001$ & $\mathrm{P}<0.0001$ & $\mathrm{P}<0.0001$ \\
\hline
\end{tabular}

Values are mean $\pm \mathrm{SE}(\mathrm{n}=3)$

Different letters ( $a, b, c$ and $d)$ in the superscript indicate significant differences at $\mathrm{p}<0.05$ within the same column.

Table 2: Mineral composition of indigenous fruit species.

\begin{tabular}{|c|c|c|c|c|c|c|c|}
\hline \multirow[b]{2}{*}{ Species names } & \multirow[b]{2}{*}{ Family names } & \multicolumn{6}{|c|}{ Composition (mg/100 g) } \\
\hline & & $\mathbf{N a}$ & Zn & $\mathbf{K}$ & $\mathbf{P}$ & $\mathbf{C a}$ & $\mathbf{F e}$ \\
\hline X. caffra & Euphorbiaceae & $0.89 \pm 0.12^{\mathrm{bc}}$ & $0.02 \pm 00^{\mathrm{ab}}$ & $671.73 \pm 9.18^{\mathrm{a}}$ & $128.29 \pm 0.88^{\mathrm{a}}$ & $23.18 \pm 0.07^{\mathrm{d}}$ & $20.39 \pm 0.20^{\mathrm{a}}$ \\
\hline S. guineense & Myrtaceae & $0.69 \pm 0.10^{\mathrm{c}}$ & $0.04 \pm 00^{\mathrm{a}}$ & $609.22 \pm 12.61^{\mathrm{a}}$ & $112.01 \pm 5.52^{\mathrm{b}}$ & $44.42 \pm 0.39^{b}$ & $1.76 \pm 0.09^{\mathrm{d}}$ \\
\hline S. cocculoides & Loganiaceae & $0.73 \pm 0.08^{\mathrm{c}}$ & $0.01 \pm 00^{\mathrm{b}}$ & $476.66 \pm 9.74^{\mathrm{b}}$ & $61.70 \pm 2.61^{\mathrm{c}}$ & $58.96 \pm 0.78^{\mathrm{a}}$ & $5.65 \pm 0.10^{\mathrm{c}}$ \\
\hline \multirow[t]{2}{*}{ U. kirkiana } & Olacaceae & $2.11 \pm 0.39^{\mathrm{a}}$ & $0.01 \pm 00^{\mathrm{b}}$ & $429.36 \pm 30.20^{\mathrm{b}}$ & $49.81 \pm 3.94^{\mathrm{c}}$ & $38.71 \pm 0.14^{\mathrm{c}}$ & $10.27 \pm 0.51^{b}$ \\
\hline & & $\mathrm{F}=10.02$ & $\mathrm{~F}=5.52$ & $F=40.76$ & $\mathrm{~F}=108.33$ & $\mathrm{~F}=422.02$ & $\mathrm{~F}=820.58$ \\
\hline \multirow[t]{2}{*}{ ANOVA } & & $\mathrm{DF}=87$ & $\mathrm{DF}=87$ & $\mathrm{DF}=87$ & $\mathrm{DF}=87$ & $\mathrm{DF}=87$ & $\mathrm{DF}=87$ \\
\hline & & $\mathrm{P}<0.0001$ & $\mathrm{P}=0.0016$ & $\mathrm{P}<0.0001$ & $\mathrm{P}<0.0001$ & $\mathrm{P}<0.0001$ & $\mathrm{P}<0.0001$ \\
\hline
\end{tabular}

Values are mean $\pm \mathrm{SE}(\mathrm{n}=3)$

Different letters ( $a, b, c$ and $d$ ) in the superscript indicate significant differences at $p<0.05$ within the same column. 
Table 3: Total phenolic content (TPC), Total flavonoid content (TFC) and Vitamin C (Vit C) of the indigenous fruit species.

\begin{tabular}{lllll}
\hline Species names & Family names & $\begin{array}{c}\text { TPC }(\text { mg GAE/ 100 g } \\
\text { fresh sample) }\end{array}$ & $\begin{array}{c}\text { TFC (mg RE/100 g } \\
\text { fresh sample) }\end{array}$ & $\begin{array}{c}\text { Vit C (mg/100 g } \\
\text { fresh sample) }\end{array}$ \\
\hline X. caffra & Euphorbiaceae & $1915.88 \pm 25.87^{\mathrm{a}}$ & $178.46 \pm 3.43^{\mathrm{a}}$ & $358.82 \pm 5.24^{\mathrm{a}}$ \\
S. guineense & Myrtaceae & $137.37 \pm 2.38^{\mathrm{d}}$ & $45.24 \pm 0.40^{\mathrm{c}}$ & $121.67 \pm 0.63^{\mathrm{b}}$ \\
S. cocculoides & Loganiaceae & $492.31 \pm 24.33^{\mathrm{b}}$ & $74.11 \pm 2.89^{\mathrm{b}}$ & $93.03 \pm 1.86^{\mathrm{c}}$ \\
U. kirkiana & Olacaceae & $255.38 \pm 23.80^{\mathrm{c}}$ & $55.97 \pm 4.35^{\mathrm{c}}$ & $53.91 \pm 1.38^{\mathrm{d}}$ \\
\hline & $\mathrm{F}=1480.7$ & $\mathrm{~F}=382.42$ & $\mathrm{~F}=2276.5$ \\
ANOVA & & $\mathrm{DF}=87$ & $\mathrm{DF}=87$ & $\mathrm{DF}=87$ \\
& $\mathrm{P}<0.0001$ & $\mathrm{P}<0.0001$ & $\mathrm{P}<0.0001$ \\
\hline
\end{tabular}

Values are mean \pm SE of three determinations.

Different letters (a, b, c and d) in the superscript indicate significant differences at $\mathrm{p}<0.05$ within the same column.

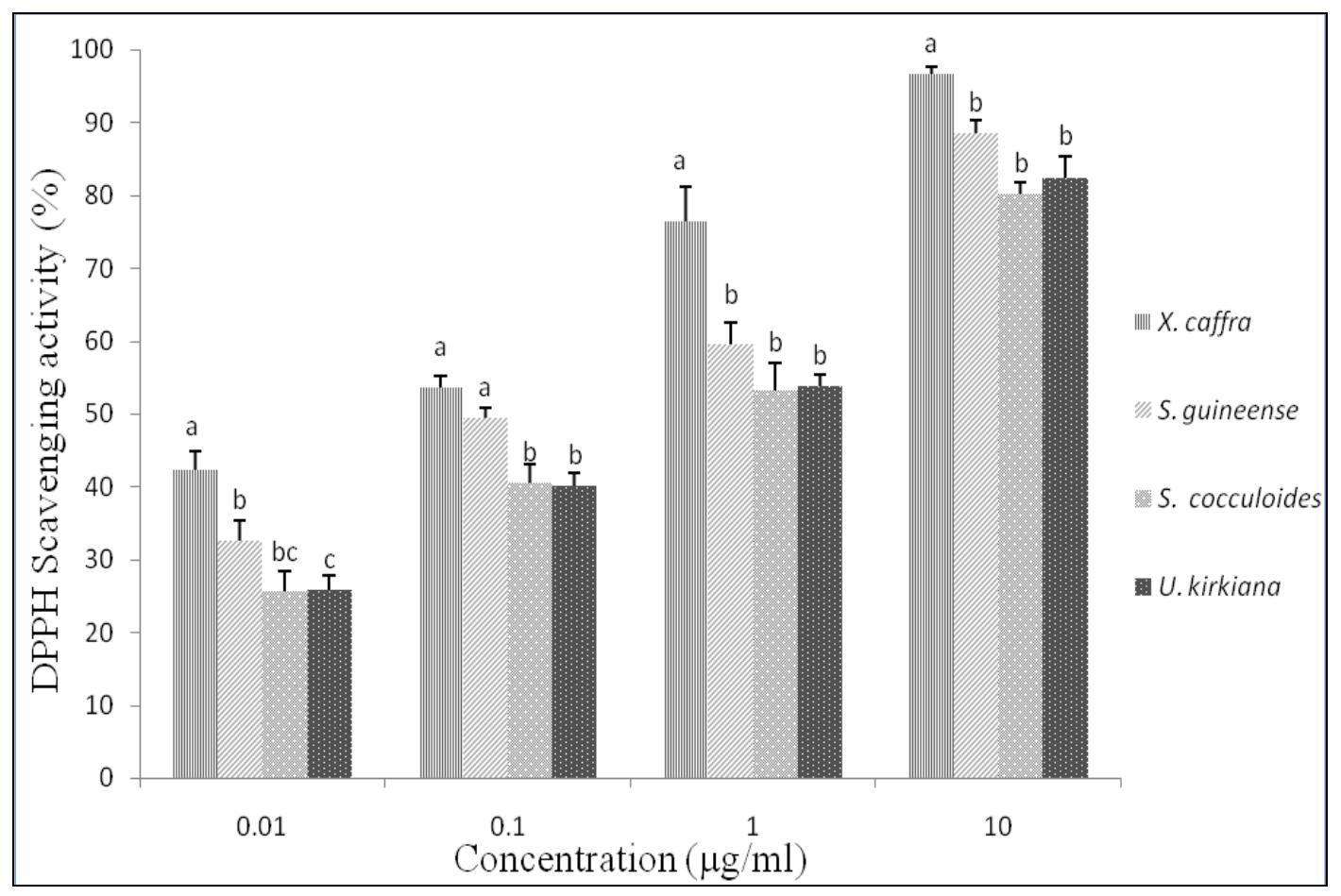

Figure 1: DPPH scavenging activities of four indigenous fruit species, values are mean \pm SE ( $\mathrm{n}=$ 3). Different letters $(a, b$, and $c)$ indicate significant differences at $\mathrm{p}<0.05$ in the same concentration range. 


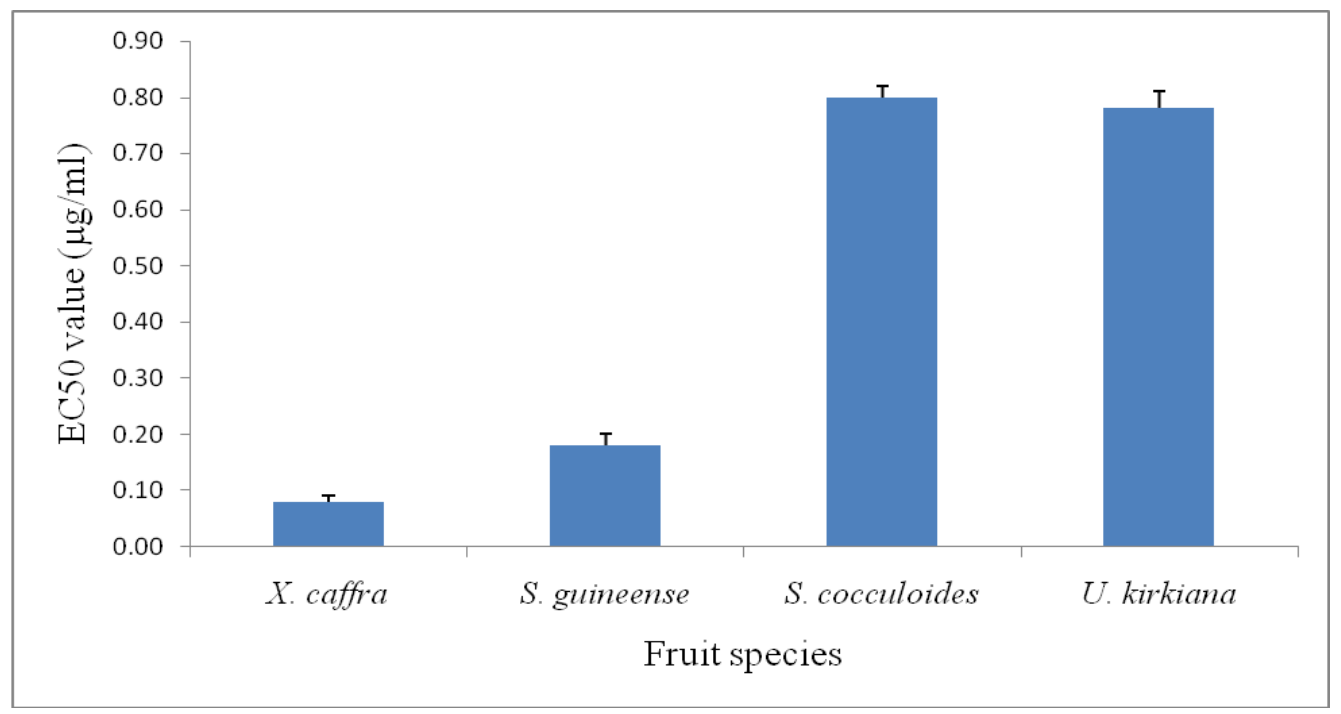

Figure 2: $\mathrm{EC}_{50}$ (amount of sample required to decrease $\mathrm{DPPH}$ concentration by $50 \%$ ) of the indigenous fruit species. Data are means $\pm \operatorname{SE}(n=3)$.

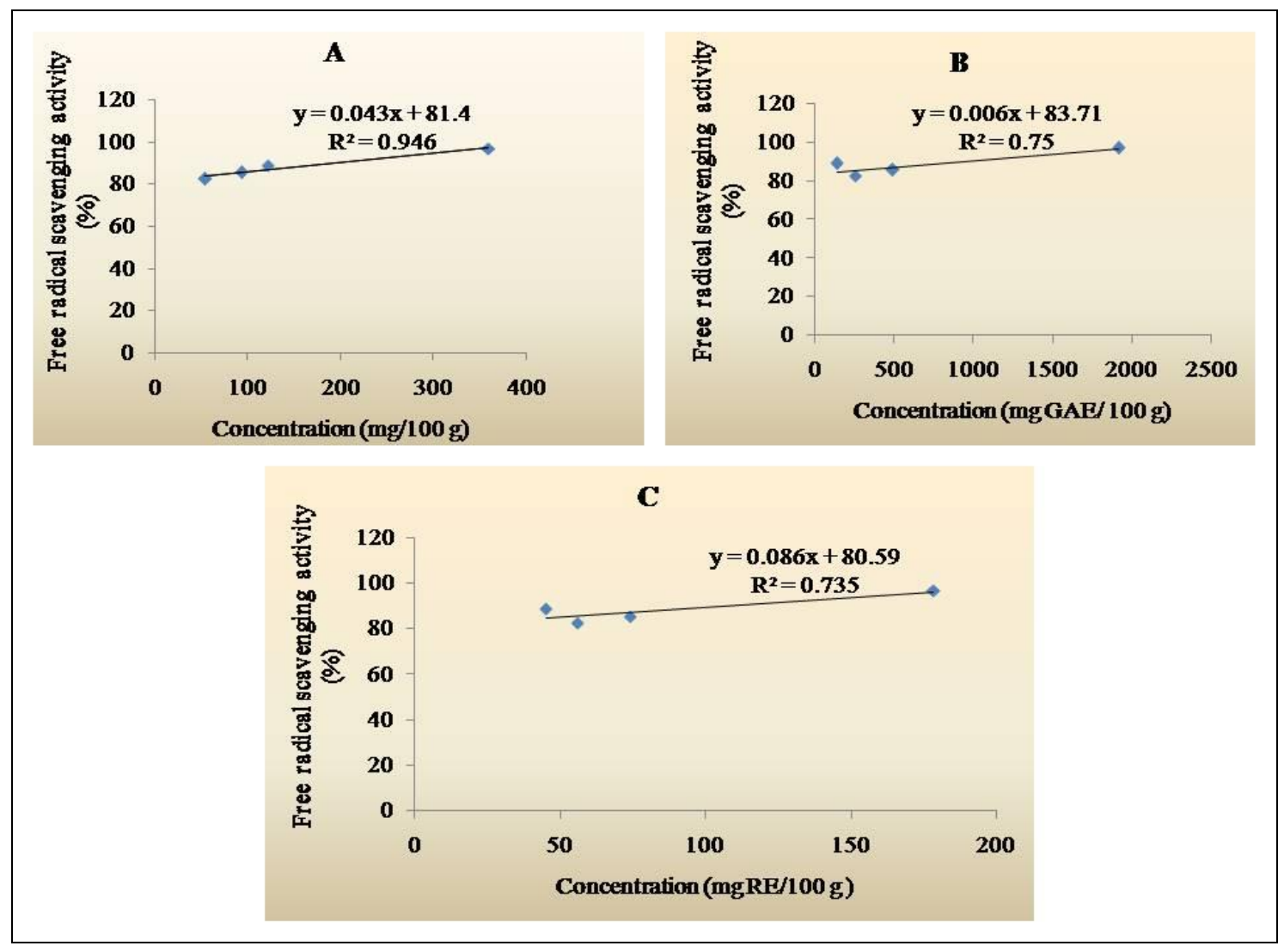

Figure 3: Relationship between antioxidant capacity and vitamin C (A), total phenolic content (B) and total flavonoid content $(\mathrm{C})$ of the indigenous fruit species. 


\section{DISCUSSION}

\section{Proximate analysis}

The results obtained in this study showed that the indigenous fruits studied are good source of moisture, protein, fiber and carbohytrate with low fat contents. Moisture contents of the indigenous fruits observed in this studied (79.49 to $85.92 \%$ ) are comparable with that reported in domesticated fruits particularly mango (77.8 to $79.1 \%$ ) and pineapple $(80.6 \%)$ the observation made by Mongi (2013). High moisture contents in fruits like that observed in this study imply that, the fruits contain low dry matter contents but also they can only be stored for a short period. Fruits that have high moisture content allow the proliferation of microorganisms and occurrence of enzymatic reactions which could spoil their quality (Bamigboye et al., 2010).

The contents of crude protein recorded in $S$. guineense, $U$. kirkiana and $X$. caffra $(0.23,0.11$ and $0.72 \%$ respectively) in this study is lower than that reported by Saka \& Msonthi (1994) in fruits of the same species from Malawi (10.1, 1.8 and $7.6 \%$ respectively). This variation might be attributed to soil characteristics and timing of fruit sampling. However, the protein content recorded in $U$. kirkiana in this study agrees with the one reported by Stadlmayr et al. (2013) in fruits from sub Saharan Africa (0.1 to $0.5 \%$ ). Lukmanji et al. (2008) reported the content of protein in domesticated fruits (mango as $0.5 \%$, banana $0.1 \%$ and pineapple $0.5 \%$ ) that are lower than that in $S$. cocculoides and X. Caffra recorded in this study, which were 0.9 and $0.7 \%$ respectively. This indicates the superiority in indigenous fruits over domesticated species, and hence they could be utilized as cheaper sources of protein in the human diet.

Fiber content observed in $S$. guineense, and $U$. kirkiana concur with those reported by Saka \& Msonthi (1994) from Malawi who found 30.3 and $8.4 \%$ respectively. The content of fibre recorded in this study is higher than those reported in orange, mango, banana, papaya and pineapple (Lukmanji et al., 2008; Mbogo et al., 2010; Mongi, 2013). Fibres are known to have many health benefits including proper functioning of the gastrointestinal tract and lowering of body fat hence low risk of cardiovascular diseases (Vasishtha \& Srivastava, 2011). The recommended daily intake for an individual is $25-30 \mathrm{~g} /$ day (Singh et al., 2016) the indigenous fruits studied can contribute better to the daily intake than the domesticated fruit species.

The fruits studied also have a high content of soluble carbohydrate and the data recorded in this study are at the same levels as reported for total carbohydrate in Annona senegalensis, Azanza garckeana, Strychnos spinosa and Strychnos innocua (Saka \& Msonthi, 1994). However, they are much higher than that of wild fruits reported by Hegazy et al. (2013) that were less than $15 \%$. Whereas the content of crude fat in the studied fruits is lower than other wild species reported by Saka \& Msonthi (1994), Ndabikunze et al., (2006) and Emmanuel et al., (2011). They are also lower than those of avocado, mango, banana and papaya that had 12, 0.2, 0.3 and $0.1 \%$ respectively according to data by Hui, (2006).

\section{Mineral composition}

The results obtained in this study showed that the indigenous fruits studied are richer in mineral nutrients than exotic fruits that are commonly consumed. Mbogo et al., (2010) reported the content of potassium in orange ranging from 162 to $172 \mathrm{mg} / 100 \mathrm{~g}$ and Lukmanji et al., (2008) reported potassium content of $156 \mathrm{mg} / 100 \mathrm{~g}$ in mango, 358 $\mathrm{mg} / 100 \mathrm{~g}$ in banana and $113 \mathrm{mg} / 100 \mathrm{~g}$ in pineapple that are lower than those of indigenous fruits recorded in this study (429 to $672 \mathrm{mg} / 100 \mathrm{~g}$ ). Potassium plays an important role in regulating body fluid, muscle contractions and sending nerve signals and the estimated daily requirement for adolescents and adults is $2000 \mathrm{mg} / \mathrm{day}$ (ASNS, 2004). The Finding of this study indicates that indigenous fruits could contribute better to the required daily intake of potassium than the domesticated fruit species. The amount of phosphorous observed in this study are similar to those reported in other indigenous fruits such as Adansonia digitata, $(53.59 \mathrm{mg} / 100 \mathrm{~g})$, Vangueria infausta $(86.86$ $\mathrm{mg} / 100 \mathrm{~g}$ ) and Vitex mombassae (103.22 $\mathrm{mg} / 100$ g) (Emmanuel et al., 2011). 
Phosphorous plays an important role in energy production as part of adenosine triphosphate and also forms an important component of deoxyribonucleic and ribonucleic acid molecule that carries genetic information (ASNS, 2004). Also adequate intake of calcium nutrient is important for the health of bones and in combination with the phosphorous provides body strength. Indigenous fruits herein studied have higher phosphorous and calcium content than those reported by USDA (2004) in exotic fruits that are frequently consumed like apple, avocado, orange and banana.

Iron contents observed in this study is also higher compared to that reported in mango, banana and pineapple by Lukmanji et al. (2008) that were $0.1,0.1$ and $0.0 \mathrm{mg} / 100 \mathrm{~g}$ respectively. Iron is an essential nutrient that carries oxygen and it is an important part of hemoglobin in red blood cells and myoglobin in muscle (Hui, 2006). The recommended dietary iron intake in human is between 10 to $15 \mathrm{mg} /$ day as reported by ASNS (2004). Finding of this study suggests indigenous fruits like $X$. caffra can be considered as a potential source of iron in the human diet. Despite the studied fruits seem to be not a good source of sodium and zinc, but the amount of sodium observed in U. kirkiana is similar to that reported in most domesticated fruit species reported by USDA (2004). Sodium in the body works with potassium to maintain proper body water distribution and blood pressure. Sodium also plays an important role in the transmission of nerve impulses and its recommended daily intake ranges from $120 \mathrm{mg} /$ day for infants to 500 $\mathrm{mg} / \mathrm{day}$ for adults and children above 10 years (ASNS, 2004).

\section{Phenolic contents}

The result indicates that indigenous fruits studied are good sources of phenolic contents. The amount of phenolics recorded in $X$. caffra is similar to that reported by Addis et al. (2013) in the same fruit species from Ethiopia. The observation of this study also showed that $X$. caffra had higher amount of phenolics than that of indigenous vegetables from Mexico, Central America and Africa that reported to have phenolic contents ranging from 200.29 to $500.99 \mathrm{mg} \mathrm{GAE} / 100 \mathrm{~g}$ (Jiménez-Aguilar \& Grusak, 2015). However, all four indigenous fruits studied have higher amounts of phenolic contents than edible wild fruits of the Mediterranean (20 to $80 \mathrm{mg}$ $\mathrm{GAE} / 100 \mathrm{~g}$ ) reported by Romojaro et al., (2013). Similary X. caffra and S. cocculoides have higher amounts of phenolic contents compared to domesticated fruits that are commonly used by communities such as mango and banana (440.6 and $362.4 \mathrm{mg}$ GAE/100 g respectively) as reported by Singh et al., (2016) and papaya (272.99 to 339.91 $\mathrm{mg}$ GAE/100g) reported by Maisarah et al. (2013). Phenolics are important group of bioactive compounds in plant materials that have antioxidant properties for human health (Bhandari et al., 2013). The findings of this study indicate that indigenous fruits are superior in total phenolic contents compared to domesticated fruits and they should be regarded as an important source of natural antioxidant in the human diet.

\section{Flavonoid contents}

This study also recorded remarkable content of flavonoids in the indigenous fruits studied. The amount observed in $X$. caffra is more than three times that in U. kirkiana. Although flavonoid contents observed in this study are lower than those reported by Jiménez-Aguilar and Grusak (2015) in wild vegetables but the amount observed in $X$. caffra is higher than those reported in papaya (53.44 to $92.95 \mathrm{mg} \mathrm{RE} / 100 \mathrm{~g}$ ) study by Maisarah et al. (2013). Flavonoids act as a powerful antioxidant and free radical scavenger in the human health (Aires et al., 2011). Therefore, the four indigenous fruit species studied could be considered to provide a better source of natural antioxidant in the human diet than the domesticated ones. These results support the idea that indigenous fruits always have higher antioxidant properties than the domesticated and this might be attributed to natural characteristics of their growing environments (Ruffo et al., 2002; Ndabikunze et al., 2006; Prasad et al., 2011).

\section{Vitamin $C$ content}

The result also indicates the presence of high amount of vitamin $\mathrm{C}$ in the evaluated 
indigenous fruit species specifically in $X$. caffra. Vitamin C content recorded in $X$. caffra is nearly two times that reported by USDA (2004) in guava $(180 \mathrm{mg} / 100 \mathrm{~g})$. The presence of higher amount of vitamin $C$ in $X$. caffra than in other wild and domesticated fruits have also been reported by Ruffo et al. (2002). In this study U. Kirkiana observed to have the lowest amount of vitamin $\mathrm{C}$ though the amount obtained is similar to those found in papaya and orange as reported by USDA (2004) and Mbogo et al. (2010). Vitamin C is an effective antioxidant compound which is less toxic and its recommended daily intake is about $60 \mathrm{mg} /$ day (Hui, 2006). However, the human body has no ability to synthesize vitamin $\mathrm{C}$ and acquires it from the daily diet therefore, indigenous fruits reported in this study could be potential sources of vitamin C in the human diet.

\section{DPPH radical scavenging activity}

The antioxidant capacity of the fruits was measured by evaluating the ability to react with free radicals using DPPH stable radical. DPPH has been widely used to evaluate the free radical scavenging effectiveness of various plant materials (Fofie et al., 2013; Zintchem et al., 2013; Agboola, 2014; Koevi, 2015). Most free radicals are constantly generated in the human body as byproducts during the normal process of oxidation and they are implicated in many human diseases including accelerated ageing, cancer, cardiovascular diseases, neurodegenerative disease and inflammation (Bhattacharya, 2015). These deleterious effects result from an imbalanced body process of free radicals production and removal that leads to their excessive accumulation such that the body defenses fail to prevent oxidative damage. Consumption of food rich in antioxidants promotes body defense systems by keeping the amount of the free radicals balanced (Boeing et al., 2012; Bhattacharya, 2015). Extracts from the fruit species herein studied have shown a strong free radical scavenging ability which was observed through reduction of DPPH to the yellow coloured diphednyl-prcryhydrazine. Ximenia caffra had higher scavenging ability with low $\mathrm{EC}_{50}$ which reflects the high phenolic contents, flavanoids and vitamin $\mathrm{C}$ contents observed compared to other species studied his observation agree to different studies reported that the antioxidant capacity of plant materials is contributed by the amount of phytonutrients they contain (Aires et al., 2011; Bhandari et al., 2013). The findings of this study showed indigenous fruits can reduce the concentration of free radicals in human body better and could be an alternate to synthetic antioxidants available in the market that might be healthy unsafe (Boeing et al., 2012).

\section{Conclusion}

The proximate composition and mineral contents of the four indigenous fruits showed significant differences among the different species, emphasizing their nutritional potential to human diet. Detailed antioxidant properties of the four species were determined for the first time. The results obtained show that the fruits studied had high antioxidant compounds and free radical reducing abilities which justify their importance for medicinal purposes. Therefore awareness of nutritional content and medicinal values of these species need to be created among communities to ensure appropriate exploitation and usage of these fruit in solving nutritional problems in the society.

\section{COMPETING INTERESTS}

The authors declare that they have no competing interests.

\section{AUTHORS' CONTRIBUTIONS}

EPM designed the experimental study and analysis of the data. CM coordinated manuscript preparation and revision. All authors approved the final version submitted.

\section{ACKNOWLEDGMENTS}

The authors extend their appreciation to Mr. Charles Kweyunga of Botany Department, University of Dar es Salaam for technical assistance in sample analysis.

\section{REFERENCES}

Addis GG, Asfaw Z, Singh V, Woldu Z, Baidu-Forson JJ, Bhattacharya S. 2013. Dietary value of wild and semi-wild 
edible plants in southern Ethiopia. Afr. $J$. Food, Agric. Nutr. Dev., 13: 7485-7503.

Agboola OS. 2014. Antioxidant potentials of local fruits and foreign wines sold in IleIfe, Nigeria. Int. J. Biol. Chem. Sci., 8:699-704.

DOI: http://dx.doi.org/10.4314/ijbcs.v8i2.26

Aires A, Fernandes C, Carvalho R, Bennett RN, Saavedra MJ, Rosa EAS. 2011. Seasonal effects on bioactive compounds and antioxidant capacity of six economically important Brassica vegetables. Molecules, 16: 6816-6832. DOI:

https://doi.org/10.3390/molecules 160868 16

Akinnifesi FK, Kwesiga F, Mhango J, Chilanga T, Mkonda A, Kadu CAC, Kadzere I, Mithofer D, Saka JDK, Sileshi G, Ramadhani T, Dhliwayo P. 2006. Towards the development of Miombo fruit trees as commercial tree crops in Southern Africa. For. trees livelihoods, 16:103-121.

Allen SE, Ed. 1989. Chemical Analysis of Ecological Materials (2nd Edition). Blackwell Scientific Publications: Oxford and London England; 46-61.

AOAC. 2000. Association of Official Analytical Chemists. 17th Edn. Official Method of Analysis, Washington D.C, USA.

ASNS (American Society for Nutritional Sciences). 2004. http://www.nutrition.org

Backéus I, Pettersson B, Strömquist L, Ruffo C. 2006. Tree communities and structural dynamics in miombo (Brachystegia-Julbernardia) woodland, Tanzania. For. Ecol. Manage., 230:171178. DOI: $10.1016 /$ j.foreco.2006.04.033

Bamigboye AY, Okafor AC, Adepoju OT. 2010. Proximate and mineral composition of whole and dehulled Nigerian sesame seed. Afr. J. Food Sci. Technol., 1: 071-075.

Bhandari SR, Jung BD, Baek HY, Lee YS. 2013. Ripening-dependent changes in phytonutrients and antioxidant activity of red pepper (Capsicum annиum L.) fruits cultivated under open-field conditions. HortScience, 48:1275-1282.
Boeing H, Bechthold A, Bub A, Ellinger S, Haller D, Kroke A, Leschik-Bonnet E, Müller MJ, Oberritter H, Schulze M, Stehle P. 2012. Critical review: vegetables and fruit in the prevention of chronic diseases. Eur. J. Nutr., 51:637663. DOI: 10.1007/s00394-012-0380-y

Bonvehi JS, Torrent MS, Lorente EC. 2001. Evaluation of polyphenolic and flavonoid compounds in honey-bee collected pollen produced in Spain. $J$. Agric. Food Chem., 49:1848-1853.

Emmanuel TV, Njoka JT, Catherine LW, Lyaruu HV. 2011. Nutritive and antinutritive qualities of mostly preferred edible woody plants in selected drylands of Iringa District, Tanzania. Pak. J. Nutr., 10:786-791. DOI: 10.3923/pjn.2011.786.791

Fofie YNGB, Sanogo R, Diarra B, Kanadjigui F, Kone-Bamba D. 2013. Antioxidant and anti-hyperglycaemic activity of Euphorbia hirta L. on Wistar rats. Int. J. Biol. Chem. Sci., 7:25582567.

DOI: http://dx.doi.org/10.4314/ijbcs.v7i6.30

Hegazy AK, Al-RowailySL, Faisal M, Alatar AA, El-Bana MI, Assaeed AM. 2013. Nutritive value and antioxidant activity of some edible wild fruits in the Middle East. J. Med. Plants Res., 7:938-946.

Hui YH. 2006. Hand book of Fruits and Fruit Processing. John Wiley \& Sons.

James CS. 1995. The Analytical Chemistry of Foods. Chapman and Hall, New York:

Jiménez-Aguila DM, Grusak MA. 2015. Evaluation of minerals, phytochemical compounds and antioxidant activity of Mexican, Central American and African green leafy vegetables. Plant Foods Hum. Nutr., 70:357-364.

Kähkönen MP, Hopia AI, Vuorela HJ, Rauha JP, Pihlaja K, Kujala TS, Heinonen M. 1999. Antioxidant activity of plant extracts containing phenolic compounds. J. Agric. Food Chem., 47:3954-3962.

Klein BP, Perry AK. 1982. Ascorbic acid and vitamin A activity in selected vegetables from different geographical areas of the United States. J. Food Sci., 47:941-945.

Koevi KKA, Millogo V, Fokou JBH, Sarr A, Ouedraogo GA, Bassene E. 2015. 
Phytochemical analysis and antioxidant activities of Combretum molle and Pericopsis laxiflora. Int. J. Biol. Chem. Sci., 9:2423-2431. DOI: http://dx.doi.org/10.4314/ijbcs.v9i5.14

Leakey RRB, Greenwell P, Hall MN, Atangana AR, Usoro C, Anegbeh PO, Fondoun JM, Tchoundjeu Z. 2005. Domestication of Irvingia gabonensis: Tree to-tree variation in food-thickening properties and in fat and protein contents of dika nut. Food Chem., 90:365-378.

Lukmanji Z, Hertzmark E, Mlingi N, Assey V, Ndossi G, Fawzi W. 2008. Tanzania Food Composition Tables. MUHASTFNC, HSPH, Dar es Salaam Tanzania.

Maisarah AM, Nurul-Amira B, Asmah R, Fauziah O. 2013. Antioxidant analysis of different parts of Carica papaya. Int. Food Res. J., 20:1043-1048.

Masuda T, Yonemori S, Oyama Y, Takeda Y, Tanaka T, Andoh T. 1999. Evaluation of the antioxidant activity of environmental plants: activity of the leaf extracts from seashore plants. J. Agric. Food Chem., 47:1749-1754.

Mbogo GP, Mubofu EB, Othman CC. 2010. Postharvest changes in physico-chemical properties and levels of some inorganic elements in off vine ripened orange (Citrus sinensis) fruits $\mathrm{cv}$ (Navel and Valencia) of Tanzania. Afr. $J$. Biotechnol., 9:1809-1815.

Mongi RJ. 2013. Solar drying of fruits and vegetables: dryers' thermal performance, quality and shelf life of dried mango, banana, pineapple and tomato. Doctoral Thesis, Sokoine University of Agriculture, Tanzania.

Ndabikunze B, Masambu N, Tiisekwa M. 2010. Vitamin $\mathrm{C}$ and mineral contents, acceptability and shelf life of juice prepared from four indigenous fruits of miombo woodlands of Tanzania. $J$. Food, Agric. Environ., 8:91-96.

Ndabikunze BK, Mugasha AG, Chcimshama SAD, Tiisekwa BPM. 2006. Nutritive Value of Selected' Forest/woodland' Edible Fruits, Seeds and Nuts in Tanzania. J. Agric. Sci., 7:27-33.

Olsen SR, Sommers LE, Page AL. 1982. Methods of soil analysis Part 2: Chemical and microbiological properties of Phosphorus. ASA Monograph., 9:403430.

Prasad NK, Hassan FA, Yang B, Kong KW Ramanan RN, Azlan A, Ismail A. 2011. Response surface optimisation for the extraction of phenolic compounds and antioxidant capacities of underutilized Mangifera pajang Kosterm. Peels. Food Chem., 128:1121-1127.

Romojaro A, Botella MÁ, Obón C, Pretel MT. 2013. Nutritional and antioxidant properties of wild edible plants and their use as potential ingredients in the modern diet. Int. J. Food Sci. Nutr., 64:944-952.

DOI: 10.3109/09637486.2013.821695

Ruffo CK, Birnie A, Tengnas BO. 2002. Edible Wild Plants of Tanzania (Vol. 27). Regional Land Management Unit/Sida.

Saka JK, Msonthi JD. 1994. Nutritional value of edible fruits of indigenous wild trees in Malawi. For. Ecol. Manage., 64:245248.

Singh JP, Kaur A, Shevkani K, Singh N. 2016. Composition, bioactive compounds and antioxidant activity of common Indian fruits and vegetables. $J$. Food Sci. Technol., 53:4056-4066.

Stadlmayr B, Charrondiere U, Eisenwagen S, Jamnadass R, Kehlenbeck K. 2013. Nutrient composition of selected indigenous fruits from sub-Saharan Africa. J. Sci. Food Agric., 93:627-2636.

USDA. 2004. National Nutrient Database for Standard Reference, Release. USDA, 161.

Vasishtha H, Srivastava RP. 2011. Effect of soaking and cooking on dietary fibre components of different type of chickpea genotypes. J. Food Sci. Technol., 50:579-584.

Zintchem R, Njinkio B, Kamgang R, Fokunang C, Tsala DE, Sida MB. 2013. Antioxidative properties of Mallotus oppositifolium decoction leaves extract using in vitro models. Int. J. Biol. Chem. Sci., $\quad 7: 2396-2408 . \quad$ DOI http://dx.doi.org/10.4314/ijbcs.v7i6.18 